\title{
Chromosomal Gene Transfer by Conjugation in the Plant Pathogen Xanthomonas axonopodis pv. vesicatoria
}

\author{
Huseyin Basim, Robert E. Stall, Gerald V. Minsavage, and Jeffrey B. Jones
}

First author: Akdeniz Universitesi, Ziraat Fakultesi, Bitki Koruma Bolumu, Antalya, Turkey; and first, second, third, and fourth authors: Department of Plant Pathology, University of Florida, Gainesville 32611.

Accepted for publication 26 July 1999.

\begin{abstract}
Basim, H., Stall, R. E., Minsavage, G. V., and Jones, J. B. 1999. Chromosomal gene transfer by conjugation in the plant pathogen Xanthomonas axonopodis pv. vesicatoria. Phytopathology 89:1044-1049.

Genes for copper resistance, located on the chromosome of strain XvP26 of Xanthomonas axonopodis pv. vesicatoria, were transferred by conjugation to a recipient strain of the bacterium. The chromosomal gene transfer was verified by analyses of the genomes of donor, recipient, and putative transconjugants for plasmid profiles, by polymorphism of DNA bands obtained by digesting total genomic DNA by a rare-cutting endonuclease and pulsed-field gel electrophoresis, and by Southern hybridization with

quency of kanamycin resistance transfer to recipient was more than 75 times greater in pepper leaves than in vitro. The transfer of chromosomal sequences containing the hypersensitive reaction and pathogenicity ( $h r p$ ) genes and pigmentation (pig) genes was linked with transfer of kanamycin resistance (Tn5). Horizontal transfer in planta of the chromosomal genes (i.e., cop, pig, hrp, and $\mathrm{Tn} 5$ sequences) among strains of $X$. axonopodis pv. vesicatoria means that horizontal chromosomal gene transfer is possible in nature. This type of gene transfer may explain the presence of great diversity among strains of the bacterial spot pathogen in terms of DNA polymorphism and may also explain the apparent horizontal transfer of hrp sequences among pathovars of Xanthomonas.
\end{abstract} a probe containing the copper genes. Transfer of kanamycin resistance to a recipient strain, associated with $\operatorname{Tn} 5$ insertion into the chromosome of another strain of the bacterial spot pathogen, was also verified. The fre-
Additional keywords: bacterial spot disease, Capsicum annuum, Lycopersicon esculentum.
Bacteria in the genus Xanthomonas cause diseases in over 124 monocotyledonous and 268 dicotyledonous plant species $(15,17)$. The genus Xanthomonas comprises 20 DNA homology groups, which are considered to be genomic species (27). The xanthomonads that cause the bacterial spot disease of pepper (Capsicum annuum L.) and tomato (Lycopersicon esculentum Mill.) exhibit significant genetic diversity in restriction fragment length polymorphism, protein profiles, fatty acid profiles, and total DNA homology (24). Stall et al. (24) divided strains of the bacterial spot pathogen into two genetic groups, and Vauterin et al. (27) placed the groups into two separate species (i.e., Xanthomonas axonopodis pv. vesicatoria [A group] and $X$. vesicatoria [B group]).

Significant variation also occurs among the bacterial spot pathogens in plasmid composition, with plasmids varying in size from 3 to 300 kilobases $(\mathrm{kb})$ among a population of 522 strains. Thirteen size classes of plasmids were differentiated, and 71 different plasmid profiles occurred among the strains (3). Most of the avirulence genes involved in host and cultivar specificities $(19,23)$ and the genes for resistance to copper and streptomycin are located on plasmids $(18,25)$. Moreover, plasmids that carry copper resistance genes are self-transmissible (25). Mobilization of plasmids among strains of $X$. axonopodis pv. vesicatoria has been demonstrated to occur in nature (3). Plasmids may also be important in gene transfer among strains of Xanthomonas. However, this type of gene transfer does not explain evidence obtained for the horizontal transfer of $h r p$ gene sequences, which are located on the chromosome (2), among pathovars of Xanthomonas (16). Horizontal chromosomal gene transfer (20) among strains of the bacterium could account for such transfer. Horizontal transfer of chromosomal genes among strains of

Corresponding author: J. B. Jones; E-mail address: jbjones@ufl.edu

Publication no. P-1999-0920-01R

(c) 1999 The American Phytopathological Society plant-pathogenic bacteria has been reported (5), but the significance of this transfer in causing genetic variation has not been studied.

The purpose of this research was to investigate if chromosomal gene transfer by conjugation occurs among strains of $X$. axonopodis pv. vesicatoria in a natural niche of the bacterium. This work was begun after discovery of a strain of $X$. axonopodis pv. vesicatoria that had copper resistance genes located on the chromosome. It was speculated that the copper genes, which are usually plasmid-borne in this bacterium, may have integrated into the chromosome and thus might mobilize the chromosome between strains. Chromosomal movement between strains of $X$. axonopodis pv. vesicatoria by conjugation in nature could be an important source of genetic variation, potentiating changes of ecological and evolutionary significance for the plant pathogen.

\section{MATERIALS AND METHODS}

Bacterial strains, plasmids, and culture conditions. The bacterial strains and plasmids used in this study and their sources are listed in Table 1. Strain XvP26, originally isolated from pepper in Taiwan, was used as one donor, and the determinants for copper resistance were located on the chromosome. Strain 85-13, isolated from pepper in Florida, was used as another donor, and transposon Tn5 was inserted into its chromosome to provide a strain with kanamycin resistance. Streptomycin-resistant mutants of both donors were obtained by selection of colonies on plates containing $200 \mu \mathrm{g}$ of streptomycin sulfate per ml. Strain $82-8$, originally isolated from pepper in Florida, was used as a recipient throughout these experiments, and colonies resistant to nalidixic acid and rifamycin were selected successively on media containing those antibiotics. Strain $82-8$ was found to be a good recipient in previous conjugation studies (25).

All strains of $X$. axonopodis pv. vesicatoria were grown on nutrient agar (NA) made from nutrient broth (Becton Dickinson, Cockeysville, MD) containing $1.5 \%$ agar. Nutrient broth cultures 
(NB) were grown for $24 \mathrm{~h}$ on a rotary shaker $(150 \mathrm{rpm})$ at $28^{\circ} \mathrm{C}$. Matings between strains were performed on nutrient yeast glycerol agar (NYGA) (8). All strains were stored in sterile tap water at room temperature and in $30 \%$ glycerol at $-70^{\circ} \mathrm{C}$. Antimicrobial agents were used to maintain selection for resistance markers at the following final concentrations: rifamycin, $80 \mu \mathrm{g} \mathrm{ml}^{-1}$; nalidixic acid, $50 \mu \mathrm{g} \mathrm{ml}^{-1}$; kanamycin sulfate, $50 \mu \mathrm{g} \mathrm{ml}^{-1}$; streptomycin, $50 \mu \mathrm{g} \mathrm{ml}^{-1}$, and copper sulfate, $200 \mu \mathrm{g} \mathrm{ml}^{-1}$.

Plant material and plant inoculation. Pepper plants (6 weeks old) of cv. Early Calwonder (ECW) were maintained in a growth chamber at 28 to $30^{\circ} \mathrm{C}$ during inoculation and incubation. The mesophyll spaces of leaves of pepper plants were infiltrated with bacterial suspensions with the aid of a 1-ml plastic syringe and 27-gauge needle. The concentrations of bacteria in suspensions in sterile tap water were approximately $10^{8} \mathrm{CFU} \mathrm{ml} \mathrm{m}^{-1}$, as determined by measuring the optical density (absorbance at $600 \mathrm{~nm}$ $\left[A_{600}\right]=0.3$ ) in a spectrophotometer (Spectronic 20; Bausch and Lomb, Inc., Rochester, NY).

Conjugation for chromosomal gene transfer. Both donor and recipient strains were grown overnight at $28^{\circ} \mathrm{C}$ on NA containing appropriate antimicrobial agents. Bacteria were collected from solid media, suspended in $1 \mathrm{ml}$ of sterile tap water, washed two times by centrifugation, and resuspended in sterile tap water. Equal amounts of donor $\left(10^{9} \mathrm{CFU} \mathrm{ml^{-1 }}\right)$ and recipient $\left(10^{9} \mathrm{CFU} \mathrm{m}{ }^{-1}\right)$ cells were mixed thoroughly by pipetting, plated on NYGA, and incubated for $0,8,16,24,48$, and $72 \mathrm{~h}$. At the designated times, bacteria were scraped from the NYGA plates, adjusted to approximately $10^{9} \mathrm{CFU} \mathrm{ml}^{-1}$, and $400 \mu \mathrm{l}$ were transferred to each of two plates of the appropriate selective media. The number of donor cells in each suspension was determined by 10 -fold serial dilution and plating proper dilutions onto media containing copper or kanamycin, depending on the donor.

As a comparison, the same bacterial mixtures were infiltrated into the mesophyll spaces of pepper leaves and subsequently incubated for $0,8,16,24,32,40$, and $48 \mathrm{~h}$ at $28^{\circ} \mathrm{C}$. After an appropriate time interval, $3 \mathrm{~cm}^{2}$ of inoculated leaf tissue was sequentially triturated in $1 \mathrm{ml}$ of sterile tap water, pelleted at $16,000 \times g$ in an Eppendorf microfuge for $2 \mathrm{~min}$, washed in $1 \mathrm{ml}$ of sterile tap water, and centrifuged at $16,000 \times g$ for $2 \mathrm{~min}$. The pellets were resuspended in $800 \mu \mathrm{l}$ of sterile tap-water and, depending upon donor strain, $400 \mu \mathrm{l}$ of the suspension was spread onto each of two plates of media containing copper, rifamycin, nalidixic acid, and chlorothalonil $\left(80 \mu \mathrm{g} \mathrm{ml}^{-1}\right)$, or kanamycin, rifamycin, nalidixic acid, and chlorothalonil $\left(80 \mu \mathrm{g} \mathrm{ml}^{-1}\right)$. Chlorothalonil was added to prevent the growth of fungi present in leaf tissue. Plates were kept at $28^{\circ} \mathrm{C}$ for 3 to 4 days. Colonies of transconjugants and donors were counted, and transfer frequencies were expressed as transconjugants per donor cell. The experiment was repeated several times, and results from a representative experiment are reported.

Mutations in pigmentation (pig) and pathogenicity (hrp) genes of the recipient strain. Cells of the recipient strain 82-8 were grown in $4 \mathrm{ml}$ of nutrient broth to the mid-log phase growth stage $\left(5 \times 10^{8} \mathrm{CFU} \mathrm{ml}{ }^{-1}\right)$. To pellet the cells, $1 \mathrm{ml}$ of the culture was centrifuged for $2 \mathrm{~min}$ at $16,000 \times g$, and the cells were resuspended in an equal volume of a Tris-maleic acid buffer at $\mathrm{pH} 6.0$ (4). A final concentration of $100 \mu \mathrm{g} \mathrm{ml}^{-1}$ of a freshly prepared solution of nitrosoguanidine (NTG) was added to the suspension of the recipient strain and incubated at 28 to $30^{\circ} \mathrm{C}$ for $30 \mathrm{~min}$. The cells were then pelleted, resuspended in sterile tap water, and 10fold dilutions were plated onto NA. White colonies were selected and one (82-8P), which was complemented back to a yellow color with a cosmid that contained cloned pigmentation genes from $X$. axonopodis pv. vesicatoria, was used as the pig- recipient strain in chromosomal gene transfer experiments. Complementation was accomplished by transferring plasmid EC744 from Escherichia coli $\mathrm{DH} 5 \alpha$ to cells of the white strain by triparental matings using pRK2073 as a helper plasmid $(9,12,22)$.

To discount revertants of the pigmentation (pig) mutation, strain $82-8 \mathrm{P}$ was grown overnight to $10^{9} \mathrm{CFU} \mathrm{m}{ }^{-1}$. The suspension was added at a final concentration of $10^{3} \mathrm{CFU} \mathrm{m}^{-1}$ to 30 test tubes containing $3 \mathrm{ml}$ of $\mathrm{NB}$, grown for $48 \mathrm{~h}$ to $10^{9} \mathrm{CFU} \mathrm{ml} \mathrm{m}^{-1}$, and dilutions from the suspension in each tube were plated on NA. White and yellow colonies were counted at appropriate dilutions to determine reversion frequency.

To obtain a $\mathrm{Hrp}^{-}$recipient strain, approximately 300 individual colonies of 82-8 selected after the NTG treatment described above were inoculated into the mesophyll of pepper leaves at a concentration of $10^{8} \mathrm{CFU} \mathrm{m}{ }^{-1}$. Plants were kept at 28 to $30^{\circ} \mathrm{C}$ for 3 days for disease development. Colonies selected for no disease development were tested for mutations in the hrp cluster by complementation experiments. The plasmid EC993 containing the hrp gene cluster was transferred by triparental conjugation from E. coli $\mathrm{DH} 5 \alpha$ to several nonpathogenic strains. Transconjugants from triparental matings were inoculated into pepper leaves to test for complementation to pathogenicity. One strain $(82-8 \mathrm{H})$ with the $h r p^{-}$phenotype that could be complemented with the cloned $h r p$ gene cluster was selected as the $h r p^{-}$recipient for the conjugation tests described later.

To discount the possibility for pathogenic revertants of the hrp mutation, strain $82-8 \mathrm{H}$ was grown overnight to $10^{9} \mathrm{CFU} \mathrm{ml}^{-1}$, added at a final concentration of $10^{3} \mathrm{CFU} \mathrm{ml^{-1 }}$ to 50 test tubes containing $3 \mathrm{ml}$ of $\mathrm{NB}$, grown for $48 \mathrm{~h}$ to $10^{9}$, and then diluted to $10^{7}$ and $10^{8} \mathrm{CFU} \mathrm{ml}{ }^{-1}$ for inoculation into pepper leaves. The inoculated plants were incubated in the greenhouse for 3 weeks and then checked for lesion development.

TABLE 1. List of bacterial strains and plasmids used

\begin{tabular}{|c|c|c|}
\hline Strains and plasmids & Relevant characteristics & Source/source of reference ${ }^{a}$ \\
\hline \multicolumn{3}{|l|}{ Bacteria } \\
\hline \multicolumn{3}{|l|}{ Xanthomonas axonopodis pv. vesicatoria } \\
\hline XvP26 & Pepper race 3, $\operatorname{Cop}^{r}$ and $\operatorname{Str}^{r}$ & R. E. Stall \\
\hline $85-13$ & Pepper race $2, \operatorname{Str}^{r}$ and $\operatorname{Kan}^{r}(\operatorname{Tn} 5)$ & R. E. Stall \\
\hline $75-3$ & Large plasmid $(284 \mathrm{~kb})$ & R. E. Stall \\
\hline E3 & Large plasmid $(213 \mathrm{~kb})$ & R. E. Stall \\
\hline $82-8 \mathrm{H}$ & $\mathrm{Hrp}^{-}$mutant of strain $82-8$ & This study \\
\hline Escherichia coli DH5 $\alpha$ & F-recA 80dlacZM15 & Bethesda Research Laboratories \\
\hline \multicolumn{3}{|l|}{$\begin{array}{l}\text { Plasmids } \\
\end{array}$} \\
\hline pLAFR3 & Tet $^{\mathrm{r}} \mathrm{rlx}^{+} \mathrm{RK} 2$ replicon & Staskawicz et al. (26) \\
\hline pEC744 & pLAFR 3 containing pig & R. E. Stall \\
\hline pEC993 & pLAFR3 containing $h r p$ & R. E. Stall \\
\hline $\mathrm{pXv} 26 \mathrm{Cu}$ & pLAFR 3 containing Cop $^{r}$ genes & Basim and Stall (1) \\
\hline pRZ102 & Contains $\operatorname{Tn} 5$ transposon & Rothstein et al. (21) \\
\hline
\end{tabular}

${ }^{a}$ Bethesda Research Laboratories, Gaithersburg, MD; R. E. Stall, University of Florida, Gainesville; and D. L. Coplin, Ohio State University, Columbus. 
Plasmid profiles. Bacterial strains were grown for 20 to $30 \mathrm{~h}$ at $28^{\circ} \mathrm{C}$ with vigorous shaking in tubes containing $3 \mathrm{ml}$ of $\mathrm{NB}$ and proper antibiotics. Cells were harvested by centrifugation, cell density was adjusted to $A_{600}=0.3$ in sterile deionized water, and plasmid DNA was extracted as described previously (3). The plasmid DNA was then subjected to electrophoresis until a bromophenol blue front had moved $10 \mathrm{~cm}$ from the well. The electrical potential was $5 \mathrm{~V} \mathrm{~cm}^{-1}$ for the submerged gel (Model H5; BRL, Grand Island, NY). Samples were electrophoresed through $0.5 \%$ agarose gels (SeaKem, DNA grade; FMC BioProducts, Rockland, ME) in Tris-acetate-EDTA buffer (0.04 M Tris-acetate and 0.001 M EDTA, $\mathrm{pH} 8.0)$, stained with ethidium bromide $\left(0.5 \mu \mathrm{g} \mathrm{ml}{ }^{-1}\right)$ for $30 \mathrm{~min}$, and photographed using transmitted UV light. In each gel, a plasmid preparation of Pantoea stewartii subsp. stewartii strain SW2 (7) was included as a molecular weight marker.

The presence of a megaplasmid in the donor, recipient, or putative transconjugants was determined by pulsed-field gel electrophoresis (PFGE) technique. Cells of donor, recipient, and transconjugants and other strains of $X$. axonopodis pv. vesicatoria, which were known to have large plasmids (Table 1), were incorporated into agarose blocks and then lysed as described previously (10). The total undigested genomic DNAs from those strains were subjected to PFGE as described below.

Preparation of genomic DNA in agarose blocks and restriction enzyme digestion. Bacterial genomic DNA in agarose blocks was prepared as described by Hacioglu et al. (14). Agarose blocks containing lysed bacterial cells were sectioned into four to five pieces, about 3- to 4-mm sections, across the width of the block with a sterile glass coverslip. The small agarose pieces were rinsed twice in $1 \mathrm{ml}$ of Tris-EDTA buffer for $1 \mathrm{~h}$. The buffer was changed, and blocks were transferred into Eppendorf tubes containing $100 \mathrm{ml}$ of $1 \times$ SpeI restriction enzyme buffer. After $20 \mathrm{~min}$, the buffer was replaced with fresh enzyme buffer, and 18 units of SpeI (Promega Corp., Madison, WI) was added. The DNA was digested overnight at $37^{\circ} \mathrm{C}$.

PFGE. Fragments of digested DNA were separated electrophoretically in $0.9 \%$ SeaKem-GTG agarose (FMC BioProducts) in $0.5 \times$ Tris-borate-EDTA buffer (TBE; $44.5 \mathrm{mM}$ Tris-HCl, $44.5 \mathrm{mM}$ boric acid, and $1 \mathrm{mM}$ EDTA, pH 8.0) by using a Bio-Rad DRII ContourClamped Homogeneous Electric Field (CHEF) apparatus (Bio-Rad Laboratories, Richmond, CA) (6). The blocks containing the digested DNA were washed with $500 \mu \mathrm{l}$ of wash solution $(0.5 \mathrm{mM}$ EDTA, $\mathrm{pH} 9.5$, and $1 \% \mathrm{~N}$-lauroyl sarcosine in sterile deionized

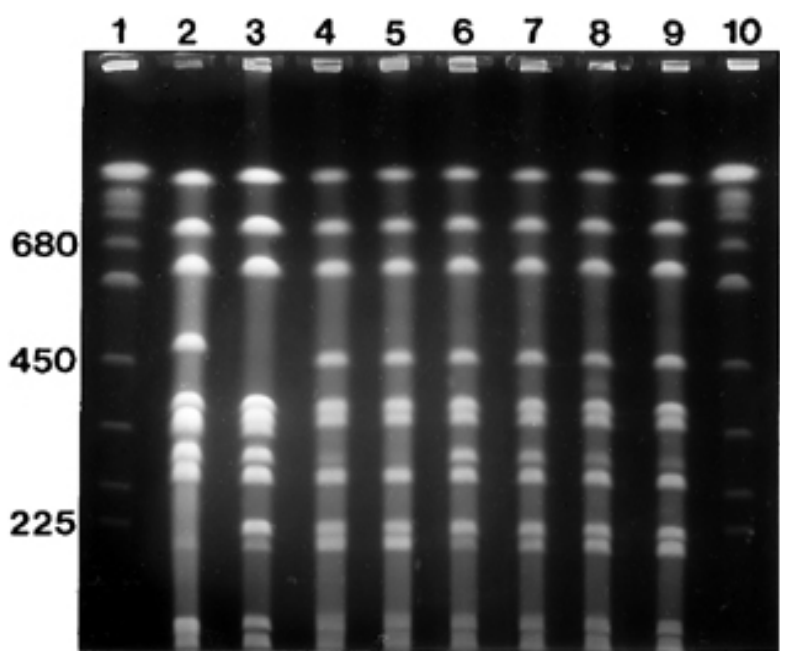

Fig. 1. Restriction profiles after pulsed-field gel electrophoresis of SpeI di-

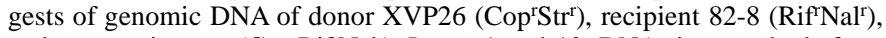
and transconjugants $\left(\mathrm{Cop}^{r} \mathrm{Rif}^{\mathrm{r} N a l^{r}}\right)$. Lanes 1 and 10, DNA size standards from Saccharomyces cerevisiae; lane 2, donor; lane 3, recipient; and lanes 4 to 9 , transconjugants. The ramped pulse times were 5 to $45 \mathrm{~s}$ for $22 \mathrm{~h}$ at $14^{\circ} \mathrm{C}$ and 200 V. The gel was $1.0 \%$ Seakem-GTG agarose in $0.5 \times$ Tris-borate-EDTA buffer. Molecular sizes of marker bands are indicated in kilobases. water) at $55^{\circ} \mathrm{C}$ for $2 \mathrm{~h}$ and were rinsed once at room temperature in $500 \mu \mathrm{l}$ of wash solution for $15 \mathrm{~min}$. The agarose blocks were then placed into $1-\mathrm{cm}$-wide wells in an agarose gel $(14 \times 12.5 \mathrm{~cm})$ and sealed with $2 \%$ Seakem-GTG agarose at $55^{\circ} \mathrm{C}$. The gel was placed in a Bio-Rad DR II CHEF unit containing 1.6 liters of $0.5 \times$ TBE buffer that was cooled to $14^{\circ} \mathrm{C}$ throughout the run. Electrophoresis was accomplished using pulse times ramped from 5 to $45 \mathrm{~s}$ for $22 \mathrm{~h}$ at $200 \mathrm{~V}$ and from 1 to $13 \mathrm{~s}$ for $12 \mathrm{~h}$ at $200 \mathrm{~V}$ for separation of the size range 225 to $2,200 \mathrm{~kb}$ and 0.13 to $194 \mathrm{~kb}$, respectively. Gels were stained with $0.5 \times$ TBE buffer containing ethidium bromide $\left(0.5 \mu \mathrm{g} \mathrm{ml}^{-1}\right)$ for $30 \mathrm{~min}$, destained with $0.5 \times \mathrm{TBE}$ buffer for $30 \mathrm{~min}$, and photographed over a UV light source with type 55 Polaroid film (Polaroid Corp., Cambridge, MA). After electrophoresis, sizes of DNA fragments were determined by measuring the distances the bands migrated compared with Saccharomyces cerevisiae chromosome markers (Bio-Rad Laboratories) and low-range PFGE markers (New England Biolabs, Inc., Beverly, MA).

Southern hybridization analysis. Southern hybridization was done as described previously (16), with slight modifications. DNA separated by PFGE was exposed to UV light for $2 \mathrm{~min}$. DNA depurination was performed in $0.25 \mathrm{~N} \mathrm{HCl}$ twice for $20 \mathrm{~min}$ on a shaker at room temperature to enhance the transfer of large DNA fragments. DNA of the plasmid pXv26Cu and the HindIII fragment of pRZ102 were labeled using the Genius Non-radioactive Chemiluminescent DNA labeling and detection kit (Boehringer Mannheim Biochemicals, Indianapolis, IN). The membranes were washed twice for $5 \mathrm{~min}$ in $2 \times \mathrm{SSC}(1 \times \mathrm{SSC}$ is $0.15 \mathrm{M} \mathrm{NaCl}$ plus $0.015 \mathrm{M}$ sodium citrate) plus $0.1 \%$ sodium dodecyl sulfate (SDS) at room temperature and then twice for $15 \mathrm{~min}$ in $0.5 \times \mathrm{SSC}$ plus $0.1 \%$ SDS at $65^{\circ} \mathrm{C}$ after hybridization. Posthybridization washes and chemiluminescent development were carried out according to the instructions of the manufacturer. For reuse, these membranes were washed in distilled water for $1 \mathrm{~min}$ and then the probe was removed by soaking them twice in $0.4 \mathrm{~N} \mathrm{NaOH}$ plus $0.1 \%$ (wt/vol) SDS for $20 \mathrm{~min}$ at $37^{\circ} \mathrm{C}$ on a shaker. Finally, the membranes were rinsed in $2 \times \mathrm{SSC}$ for $2 \mathrm{~min}$ and then dried at room temperature until use.

\section{RESULTS}

Selection of putative transconjugants in vitro. When strain $\mathrm{XvP} 26 \mathrm{Cop}^{\mathrm{r}} \mathrm{Str}^{\mathrm{r}}$ was mated in vitro with strain 82-8 $\mathrm{Rif}^{\mathrm{r}} \mathrm{Nal}^{\mathrm{r}}$ for $24 \mathrm{~h}$, putative transconjugants developed on NA medium containing copper, nalidixic acid, and rifamycin. The frequency was low (approximately $1 \times 10^{-9}$ transconjugants per donor cell). However, no growth

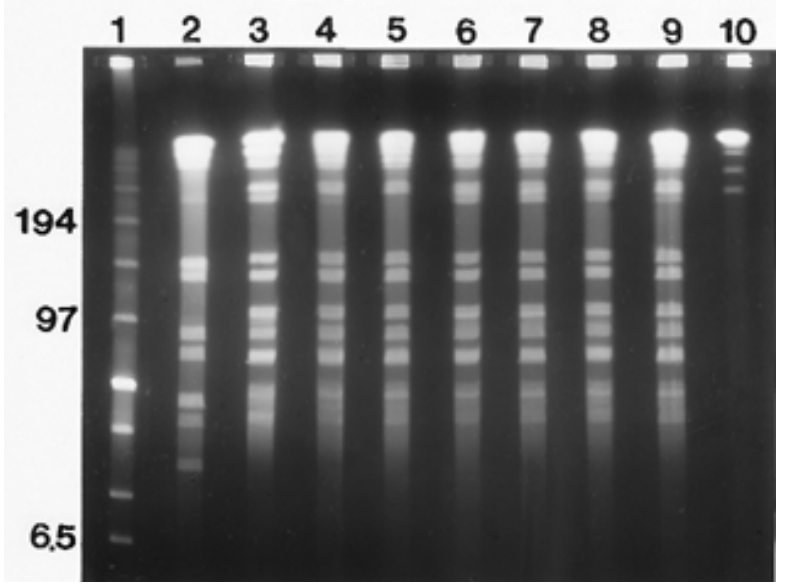

Fig. 2. DNA fragments after pulsed-field gel electrophoresis (PFGE) of SpeI digests of genomic DNA of donor 85-13 $\left(\mathrm{Kan}^{\mathrm{r}} \mathrm{Str}^{\mathrm{r}}\right)$, recipient 82-8 (RifrNalr), and transconjugants $\left(\mathrm{Kan}^{\mathrm{r}} \mathrm{Rif}^{\mathrm{r}} \mathrm{Nal}^{\mathrm{r}}\right.$ ). Lane 1, low-range PFGE marker; lane 2, donor; lane 3, recipient; lanes 4 to 9, transconjugants; and lane 10, DNA size standards from Saccharomyces cerevisiae. The ramped pulse times were 1 to $13 \mathrm{~s}$ for $12 \mathrm{~h}$ at $14^{\circ} \mathrm{C}$ and $200 \mathrm{~V}$. The gel was $1.0 \%$ Seakem-GTG agarose in $0.5 \times$ Trisborate-EDTA buffer. Molecular sizes of marker bands are indicated in kilobases. 
occurred on NA medium containing streptomycin, copper, nalidixic acid, and rifamycin. Similarly, when strain 85-13 $\operatorname{Kan}^{\mathrm{r}} \operatorname{Str}^{\mathrm{r}}$ was used as the donor, putative transconjugants were not found on NA medium containing streptomycin, kanamycin, nalidixic acid, and rifamycin. However, if streptomycin was omitted from the medium, a low number (approximately $1 \times 10^{-9}$ putative transconjugants per donor cell) were obtained.

Copper-resistant or kanamycin-resistant mutants of the recipient could account for growth of putative transconjugants on the selective medium, because resistance to only one additional compound was needed for growth of the recipient on the antimicrobial medium. However, in repeated tests, colonies of the recipient strain were not found on the selective media on which putative transconjugants were able to grow. Furthermore, no mutants of the recipient developed on NA medium plates with copper or kanamycin when approximately $10^{9}$ cells were spread over the agar surface. Nevertheless, to confirm that mobilization of the chromosome from donor to recipient occurred, plasmid profiles, PFGE, and Southern hybridizations were performed as described below.

To determine if conjugation was the mechanism responsible for movement of kanamycin resistance into the recipient, nalidixic acid, which inhibits DNA replication, was added to the medium during mating of the donor and recipient, because DNA synthesis would be required in the donor. When the donor and recipient were sensitive and resistant, respectively, to nalidixic acid, no putative transconjugants were detected. However, when the donor and recipient were resistant and sensitive, respectively, to nalidixic acid, a low number (approximately $1 \times 10^{-10}$ putative transconjugants per donor cell) were identified that were resistant to kanamycin.

Analysis of plasmid profiles of donor, recipient, and putative transconjugants. The plasmid profiles of the two donor strains and the recipient strain were different. The donor strain, XvP26 Cop $^{\mathrm{r} S t r}{ }^{\mathrm{r}}$, contains a $15-\mathrm{kb}$ plasmid, and the donor strain, 85-13 $\operatorname{Kan}^{\mathrm{r}} \mathrm{Str}^{\mathrm{r}}$, has two plasmids of 300 and $40 \mathrm{~kb}$ in size. The recipient strain, 82-8 $\mathrm{Rif}^{\mathrm{r}} \mathrm{Nal}^{\mathrm{r}}$, has three plasmids in size of about 120,44 , and $33 \mathrm{~kb}$. The putative transconjugants $\mathrm{Cop}^{r} \mathrm{Rif}^{\mathrm{r}} \mathrm{Nal}^{\mathrm{r}}$ and $\mathrm{Kan}^{\mathrm{r}} \mathrm{Rif}^{\mathrm{r}} \mathrm{Nal}{ }^{\mathrm{r}}$ had the same plasmid profile as the recipient (data not shown).

Another possibility for resistance to antimicrobial compounds in the putative transconjugants would be the movement of a megaplasmid between strains that contained $\mathrm{Cop}^{\mathrm{r}}$ or $\mathrm{Kan}^{\mathrm{r}}$. Two lines of evidence point to the lack of a megaplasmid. First, no megaplasmid was detected by the plasmid extraction procedure used. Second, large plasmids (approximately $300 \mathrm{~kb}$ ) were detected by PFGE

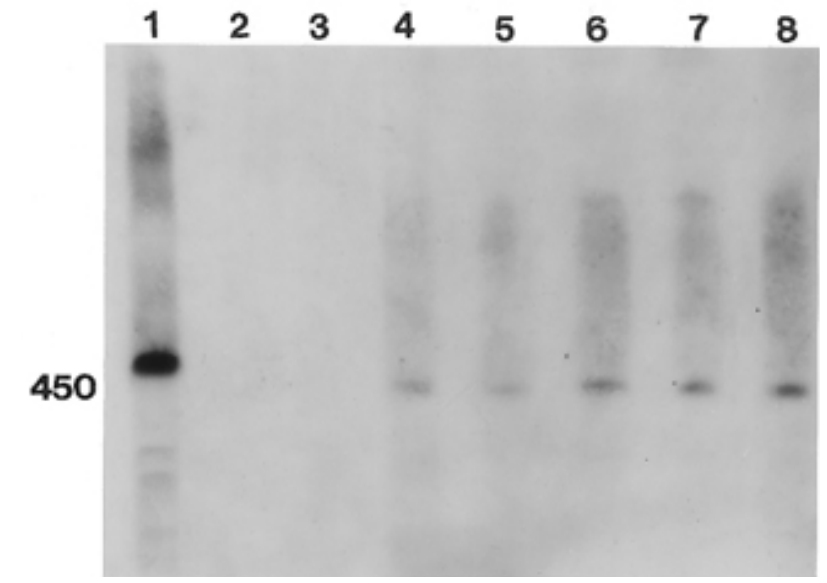

Fig. 3. Hybridization of labeled DNA of $\mathrm{pXv} 26 \mathrm{Cu}$ containing the copper gene cluster of strain XvP26 of Xanthomonas axonopodis pv. vesicatoria to genomic DNA (450-kilobase fragment) of donor XvP26 ( $\left.\mathrm{Cop}^{\mathrm{r} S t r}{ }^{\mathrm{r}}\right)$, recipient 82-8 $\left(\mathrm{Rif}^{\mathrm{r}} \mathrm{Nal}^{\mathrm{r}}\right)$, and transconjugants $\left(\mathrm{Cop}^{\mathrm{r}} \mathrm{Rif}^{\mathrm{r}} \mathrm{Nal}{ }^{\mathrm{r}}\right)$. Lane 1, donor; lane 2, recipient; lanes 3, empty; and lanes 4 to 8, transconjugants. Genomic DNA was restricted with $S p e$ I and separated by pulsed-field gel electrophoresis. The ramped pulse times were 5 to $45 \mathrm{~s}$ for $22 \mathrm{~h}$ at $14^{\circ} \mathrm{C}$ and $200 \mathrm{~V}$. The gel was $1.0 \%$ Seakem-GTG agarose in $0.5 \times$ Tris-borate-EDTA buffer. of undigested DNA in strains E3 and 75-3 of $X$. axonopodis pv. vesicatoria, but none were detected in donor strain $\mathrm{XvP} 26$, recipient, or putative transconjugants in the PFGE tests (data not shown).

Analysis of total genome profiles of donor, recipient, and putative transconjugants by PFGE. The fragment profiles of the donor and recipient strains differed after digestion of genomic DNA with SpeI and PFGE. The fragment profiles of the transconjugants $\left(\mathrm{Cop}^{\mathrm{r}} \mathrm{Rif}^{\mathrm{r}} \mathrm{Nal}^{\mathrm{r}}\right)$ were different from genomic profiles of the donor strain or recipient strain in the range of 225 to $2,000 \mathrm{~kb}$ in size (Fig. 1), but they were like the recipient strain in the range of 100 to $225 \mathrm{~kb}$ in size (data not shown). A fragment at approximately $500 \mathrm{~kb}$ was present in donor and transconjugants, but not in the recipient parent. Similarly, the putative $\operatorname{Kan}^{\mathrm{r}}$ transconjugants $\left(\operatorname{Kan}^{\mathrm{r}} \mathrm{Rif}^{\mathrm{r}} \mathrm{Nal}^{\mathrm{r}}\right.$ ) mainly shared a similar genomic profile with the recipient in the range of 225 to $2,000 \mathrm{~kb}$ (data not shown), but they were different from the donor and recipient in the range of 50 to $225 \mathrm{~kb}$ in size (Fig. 2). However, an approximately 100-kb fragment was present in recipient and transconjugants, but not in the donor parent.

Southern hybridization of genomic DNA with genes for copper resistance and Tn5 sequences. Hybridization of the genomic DNA, separated by PFGE after digestion with SpeI, with DNA from clones carrying copper resistance genes and $T n 5$ sequences, which contained the kanamycin resistance gene, located the resistance genes. Copper resistance was located on a nearly $500-\mathrm{kb}$ DNA fragment of the donor strain, $\mathrm{XvP26}$, and on fragments of approximately $450-\mathrm{kb}$ DNA in the putative transconjugants. No hybridization of copper genes occurred with DNA of the recipient strain (Fig. 3). There was little or no variation in fragment size within the transconjugants. The Tn5 sequences inserted in the chromosome of donor strain 85-13 were detected on a fragment of $86.8 \mathrm{~kb}$ in the donor and putative transconjugants by using the probe of $\operatorname{Tn} 5$ sequences. No hybridization occurred with the recipient (Fig. 4).

Matings performed in pepper plants. Experiments on linkages of copper resistance and kanamycin resistance to other chromosomal genes were limited by the low frequency of conjugation on agar media. Matings made in pepper leaves increased the frequency of transconjugants obtained with kanamycin resistance approximately 75 -fold over that obtained in vitro (data not shown). Transconjugants increased in pepper leaves with increasing mating time (Table 2). A subset of putative transconjugants selected after matings in pepper leaves were determined to be true transconjugants by comparisons with donor and recipient DNA fragment

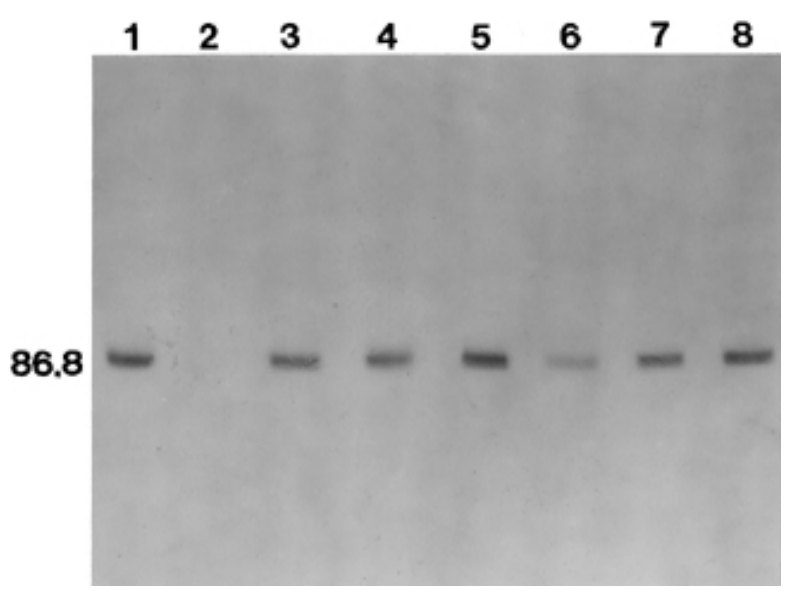

Fig. 4. Hybridization of labeled DNA of clone pRZ102 containing Tn 5 sequences to genomic DNA (86.8-kilobase fragment) of donor 85-13 (Kan $\left.{ }^{r} \operatorname{Str}^{r}\right)$,

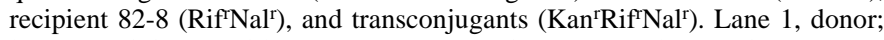
lane 2, recipient; and lanes 3 to 8 , transconjugants. Total genomic DNA was restricted with SpeI and separated by pulsed-field gel electrophoresis. The ramped pulse times were 1 to $13 \mathrm{~s}$ for $12 \mathrm{~h}$ at $14^{\circ} \mathrm{C}$ and $200 \mathrm{~V}$. The gel was $1.0 \%$ Seakem-GTG agarose in $0.5 \times$ Tris-borate-EDTA buffer. 
profiles after digestion with SpeI and separation by PFGE and by subsequent probing with copper and kanamycin resistance genes (data not shown). The numbers of transconjugants obtained were sufficient to test linkages of these genes with other chromosomal genes.

Transfer of pigmentation genes. The kanamycin-resistant donor was mated in pepper leaves with the mutant recipient that was deficient in production of pigment. Of 400 transconjugants, $90 \%$ (those colonies that grew on $\mathrm{Kan}^{\mathrm{r}} \mathrm{Rif}^{\mathrm{r}} \mathrm{Nal}^{\mathrm{r}}$ ) were yellow. Ten transconjugants were randomly selected, and they had exactly the same plasmid profile as the recipient strain. The total genomic profiles of transconjugants $\left(\mathrm{Kan}^{\mathrm{r}} \mathrm{Rif}^{\mathrm{r}} \mathrm{Nal}^{\mathrm{r}}\right.$ pig $^{+}$) after SpeI digestion of total DNA and PFGE were different from the donor and recipient strains. Tn 5 sequences were detected by Southern hybridizations on DNA fragments of the donor and transconjugants, but were not detected on fragments of the recipient. The pigmentation genes and $\mathrm{Tn} 5$ sequences of the donor and transconjugants were located on the same 86.8 -kb fragment as determined by Southern hybridization (data not shown). In recipient controls, 468 colonies were counted on 30 plates and all had the pig phenotype. Furthermore, at the next lower dilution, no pig $^{+}$colonies were evident.

Horizontal transfer of hrp genes. The kanamycin-resistant donor was mated in pepper leaves with the $\mathrm{Hrp}^{-}$recipient, $82-8 \mathrm{H}$. A group of putative transconjugants $\left(\mathrm{Kan}^{\mathrm{r}} \mathrm{Rif}^{\mathrm{r}} \mathrm{Nal}^{\mathrm{r}}\right)$ were confirmed to be transconjugants by plasmid profiles, PFGE fragment profiles, and Southern hybridizations using $\operatorname{Tn} 5$ sequences as a probe. Of the 400 transconjugants inoculated into pepper leaves, $5 \%$ were pathogenic. Thus, horizontal transfer of chromosomal hrp genes to the recipient occurred as determined by recombination and restoration of pathogenicity.

In the investigation of the total genome profiles of donor, recipient, and transconjugants, the DNA of the $86.8-\mathrm{kb}$ SpeI fragment of the donor and transconjugants, but not the recipient, again hybridized with the Tn5 clone. The hrp genes were located on a $610-\mathrm{kb}$ SpeI fragment of the donor, recipient, and transconjugants by Southern hybridization using the hrp genes as a probe (data not shown).

In a test designed to determine if $\mathrm{hrp}^{+}$revertants occurred, no typical lesions were observed on inoculated leaves at $\leq 10^{8} \mathrm{CFU} / \mathrm{ml}$. To discount inhibition of the $\mathrm{Hrp}^{+}$donor by high populations of recipient strain $82-8 \mathrm{H}$, mixtures consisting of $10^{3} \mathrm{CFU}$ of the wild type per $\mathrm{ml}$ and $10^{6}$ or $10^{7} \mathrm{CFU}$ of strain $82-8 \mathrm{H}$ per $\mathrm{ml}$ were injected into pepper leaves. Lesions were observed on leaves infiltrated with the mixtures at both concentrations of strain $82-8 \mathrm{H}$, although significantly fewer were evident at the higher concentration of strain $82-8 \mathrm{H}$.

\section{DISCUSSION}

In this study, we confirmed chromosomal transfer via conjugation for strains of $X$. axonopodis pv. vesicatoria. The plasmid profiles confirmed that the putative transconjugants were derived from the recipient. The recipient strain did not have copper or kanamycin resistance; therefore, probing with DNA containing those genes confirmed that they had been transferred to recipient cells

TABLE 2. Transfer of chromosomal Tn5 sequences from a donor to recipient strain of Xanthomonas axonopodis pv. vesicatoria after matings in planta for different times

\begin{tabular}{lc}
\hline Mating time $(\mathrm{h})$ & Frequency of transconjugants $^{\mathrm{a}}$ \\
\hline 0 & 0 \\
8 & 0 \\
16 & $1.5 \times 10^{-7}$ \\
24 & $4.7 \times 10^{-7}$ \\
32 & $8.7 \times 10^{-7}$ \\
40 & $2.0 \times 10^{-6}$ \\
48 & $2.6 \times 10^{-6}$ \\
\hline
\end{tabular}

a Values were calculated by determining the number of donor cells and transconjugants per donor cell at the end of the mating period. from the donor. The transfer of the copper genes resulted in little or no polymorphism among the transconjugants in the SpeI fragment that contained the copper genes. Thus, it appears that the same size fragment from the donor recombined into the recipient chromosome after conjugation. The SpeI fragment that contained the Tn5 transposon (kanamycin resistance) in the donor was relatively small $(86.8 \mathrm{~kb})$, and Tn5 was integrated into the same size SpeI fragment in the recipient chromosome after conjugation. Interestingly, the genes for pigmentation and the Tn5 insertion sites were located on the same SpeI fragment; therefore, selection for kanamycin resistance also selected for pigmentation complementation of recipients in $90 \%$ of the transconjugants. The two characters were thus closely linked. Furthermore, it does not appear that $\mathrm{Tn} 5$ hopped on and off a plasmid, thereby only transferring $\mathrm{Kan}^{\mathrm{r}}$. Selection for kanamycin-resistant transconjugants only resulted in linkage with $h r p$ genes in 5\% of the transconjugants. Thus, the Tn5 insertion site was not as closely linked to the hrp cluster as it was to the pig genes, which was supported by the fact that the genetic determinants for pigmentation and hrp functions were located on different SpeI fragments. The two determinants are separated by at least one SpeI restriction site, resulting in the two fragments being separated after SpeI digestion of genomic DNA. This is further evidence that a region of the chromosome containing the genes for kanamycin resistance, pigmentation, $h r p$, and specific SpeI restriction sites was occasionally recombined into the recipient chromosome.

A very low frequency of chromosomal transfer ws detected after matings on NYGA medium. The frequency was sufficient to obtain evidence for horizontal transfer of chromosomal DNA, but the frequency was not sufficient to obtain enough colonies for linkage studies. Fortuitously, the frequency of chromosomal transfer after matings in pepper leaves increased nearly 75 -fold. The numbers of transconjugants obtained were sufficient to test for linkages of markers with other characteristics. The increase in conjugation in pepper leaves compared with artificial media may mean that conjugation is induced in planta, as it is for the Ti plasmid of Agrobacterium tumefaciens (11). Further study of this phenomenon could lead to the discovery of a plant product that could increase chromosomal transfer in vitro.

Two strains of $X$. axonopodis pv. vesicatoria were used as donors for this work. The two strains were obtained from widely different locations (Florida and Taiwan), but both belong to the A group of strains (27). One of the strains, XvP26, had only one plasmid of $15 \mathrm{~kb}$ in size. The other strain, 85-13, had two resident plasmids. The role of the resident plasmids in the movement of chromosomal DNA between the strains of $X$. axonopodis pv. vesicatoria was not completely determined, but their role is thought to be minor. The presence of Tn 5 in both a plasmid and chromosome has been reported to result in plasmid integration into the chromosome and transfer of chromosomal genes (4). In this study, Tn5 only occurred in the chromosome of strain 85-13, so integration of a resident plasmid into the chromosome should not have been aided by the Tn 5 transposon. The horizontal transfer of chromosomal DNA with these strains was accomplished without the use of introduced plasmids or phages that aid in chromosomal movement, as previously reported for chromosomal transfer among other strains of plant-pathogenic bacteria (5).

Chromosomal transfer resulted in polymorphism of DNA fragments obtained by endonuclease digestion of genomic DNA. Thus, chromosomal transfer may account for the extensive polymorphism seen among genomic fragments of closely related strains within the genus Xanthomonas (10). If so, extensive polymorphism within closely related strains may be indicative of extensive horizontal transfer of genes. The procedure may be useful to test for chromosomal movement between pathovars of the same species and between species of Xanthomonas.

The movement of chromosomal DNA will help in mapping the chromosomal genes of $X$. axonopodis pv. vesicatoria. A primitive 
physical map has been developed (13), but numerous genes that are important in plant pathogenicity and taxonomy have not been placed on the map. Groups of linked genes may be established by randomly inserting Tn5 into the chromosome and determining movement of the genes along with kanamycin resistance. Possibly the linked genes could aid in the sequential location of DNA fragments after digestion of genomic DNA by rare-cutting endonucleases and Southern hybridization with the genes. This procedure aided in the sequential location of two important gene clusters in this work.

\section{ACKNOWLEDGMENTS}

Florida Agricultural Experiment Station, Journal Series R-06968.

\section{LITERATURE CITED}

1. Basim, H., and Stall, R. E. 1996. A unique chromosomal copper resistance gene cluster from Xanthomonas axonopodis pv. vesicatoria. (Abstr.) Phytopathology 86(suppl.):S15-16.

2. Bonas, U., Schulte, R., Fenselau, D., Minsavage, G., Staskawicz, B., and Stall, R. 1991. Isolation of a gene cluster from Xanthomonas campestris pv. vesicatoria that determines pathogenicity and the hypersensitive response on pepper and tomato. Mol. Plant-Microbe Interact. 4:81-88.

3. Canteros, B. I., Minsavage, G. V., Jones, J. B., and Stall, R. E. 1995. Diversity of plasmids in Xanthomonas campestris pv. vesicatoria. Phytopathology 85:1482-1486.

4. Carlton, B. C., and Brown, B. J. 1981. Gene mutation. Pages 222-242 in: Manual of Methods for General Bacteriology. P. Gerhard, R. G. E. Murray, R. N. Costilow, E. W. Nester, W. A. Wood, N. R. Krieg, and G. B. Phillips, eds. American Society of Microbiologists, Washington, DC.

5. Chatterjee, A. K., and Vidaver, A. K. 1986. Advances in Plant Pathology, Vol. 4. Genetics of Pathogenicity Factors: Application to Phytopathogenic Bacteria. Academic Press \& Harcourt Brace Jovanovich, New York.

6. Chu, G., Vollrath, D., and Davis, R. W. 1986. Separation of large DNA molecules by contour-clamped homogenous electric fields. Science 234: $1582-1585$.

7. Coplin, D. L., Rowan, R. G., Chisholm, D. A., and Whitmoyer, R. E. 1981. Characterization of plasmids in Erwinia stewartii. Appl. Environ. Microbiol. 42:599-604.

8. Daniels, M. J., Barber, C. E., Turner, P. C., Cleary, W. G., and Sawczyc, M. K. 1984. Isolation of mutants of Xanthomonas campestris showing altered pathogenicity. J. Gen. Microbiol. 130:2447-2455.

9. Ditta, G., Stanfield, S., Corbin, D., and Helinski, D. 1980. Broad host range DNA cloning system for gram negative bacteria: Construction of a gene bank of Rhizobium meliloti. Proc. Natl. Acad. Sci. U.S.A. 77:7347-7351.

10. Egel, D. S., Graham, J. H., and Stall, R. E. 1991. Genomic relatedness of Xanthomonas campestris strains causing diseases of citrus. Appl. Environ. Microbiol. 57:2724-2730.

11. Farrand, S. K. 1993. Conjugal transfer of Agrobacterium plasmids. Pages 255-291 in: Bacterial Conjugation. D. B. Clewell, ed. Plenum Press, New York.
12. Figurski, D., and Helinski, D. R. 1979. Replication of an origin containing derivative of plasmid RK2 dependent on a plasmid function provided in trans. Proc. Natl. Acad. Sci. U.S.A. 76:1648-1652.

13. Hacioglu, E., Basim, H., and Stall, R. E. 1996. Rarely-cutting restriction endonucleases useful for determining genome size and physical map of the chromosome of Xanthomonas axonopodis pv. vesicatoria. (Abstr.) Phytopathology 86(suppl.):S77.

14. Hacioglu, E., Basim, H., and Stall, R. E. 1997. Optimized conditions of PacI and SwaI for genome analysis of Xanthomonas axonopodis pv. vesicatoria by PFGE. Biotechniques 22:1026-1028.

15. Hayward, A. C. 1993. The hosts of Xanthomonas. Pages 1-19 in: Xanthomonas. J. G. Swings and E. L. Civerolo, eds. Chapman \& Hall, London.

16. Leite, Jr., R. P., Minsavage, G. V., Bonas, U., and Stall, R. E. 1994. Detection and identification of phytopathogenic Xanthomonas strains by amplification of DNA sequences related to the hrp genes of Xanthomonas campestris pv. vesicatoria. Appl. Environ. Microbiol. 60:1068-1077.

17. Leyns, F., DeCleene, M., Swings, J. G., and De Ley, J. 1984. The host range of genus Xanthomonas. Bot. Rev. 50:308-356.

18. Minsavage, G. V., Canteros, B. I., and Stall, R. E. 1990. Plasmid-mediated resistance to streptomycin in Xanthomonas campestris pv. vesicatoria. Phytopathology 80:719-723.

19. Minsavage, G., Dahlbeck, D., Whalen, M., Kearny, B., Bonas, U., Staskawicz, B., and Stall, R. 1990. Gene-for-gene relationships specifying disease resistance in Xanthomonas campestris pv. vesicatoria-pepper interactions. Mol. Plant-Microbe Interact. 3:41-47.

20. Provence, D. L., and Curtis, Jr., R. 1994. Gene transfer in gram-negative bacteria. Pages 317-347 in: Methods for General and Molecular Bacteriology. P. Gerhardt, R. G. E. Murray, W. A. Wood, and N. R. Drieg, eds. American Society of Microbiologists, Washington, DC.

21. Rothstein, S. J., Jorgensen, R. A., Yin, J. C.-P., Yong-Di, Z., Johnson, R. C., and Reznikoff, W. S. 1981. Cold Spring Harbor Symposia on Quantitative Biology. V. 45. Cold Spring Harbor Laboratory, Cold Spring Harbor, NY.

22. Sawczyc, M. K., Barber, C. E., and Daniels, M. J. 1989. The role in pathogenicity of some related genes in Xanthomonas campestris pathovars campestris and translucens: A shuttle strategy for cloning genes required in pathogenicity. Mol. Plant-Microbe Interact. 2:249-255.

23. Stall, R. E. 1995. Xanthomonas campestris pv. vesicatoria. Pages 167184 in: Pathogenesis and Host Specificity in Plant Disease: Histopathology, Biochemical, Genetic, and Molecular Bases. Vol. I: Prokaryotes. U. S. Singh, R. P. Singh, and K. Kohmoto, eds. Pergamon, Elsevier Science, Inc., Tarrytown, NY.

24. Stall, R., Beaulieu, C., Egel, D., Hodge, N., Leite, R., Minsavage, G., Bouzar, H., Jones, J., Alvarez, A., and Benedict, A. 1994. Two genetically diverse groups of strains are included in Xanthomonas campestris pv. vesicatoria. Int. J. Syst. Bacteriol. 44:47-53.

25. Stall, R. E., Loschke, D. C., and Jones, J. B. 1986. Linkage of copper resistance and avirulence loci on a self-transmissible plasmid in Xanthomonas campestris pv. vesicatoria. Phytopathology 76:240-243.

26. Staskawicz, B., Dahlbeck, D., Keen, N., and Napoli, C. 1987. Molecular characterization of cloned avirulence genes from race 0 and race 1 of Pseudomonas syringae pv. glycinea. J. Bacteriol. 169:5789-5794.

27. Vauterin, L., Hoste, B., Kersters, K., and Swings, J. 1995. Reclassification of Xanthomonas. Int. J. Syst. Bacteriol. 45:472-489. 